\title{
Strategic Global Partnership to Cultivate Health Management Education: A North and South American Model
}

\section{J. Szydlowski (Steven J. Szydlowski)}

Health Administration \& Human Resources,

$4^{\text {th }}$ Floor McGurrin Hall, Scranton, PA 18510-4699

\section{E-mail address:}

steven.szydlowski@scranton.edu

\section{Reprint address:}

Health Administration \&

Human Resources

$4^{\text {th }}$ Floor McGurrin Hall

Scranton, PA 18510-4699

Suource: Clinical Social Work and Health Intervention

Volume: 7

Issue: 4

Pages: $67-70$

Cited references: 8

\section{Reviewers:}

Dr. Johnson Nzau Mavole, Ph.D.

Catholic university of Eastern Africa, Nairobi, Kenya

e-mail: jmavole@cuea.edu

prof. MUDr. Juraj Benca, PhD.

Vysoká škola zdravotníctva a sociálnej práce sv. Alžbety, Bratislava

e-mail: benca@vssvalzbety.sk

\section{Key words:}

Global health, competency-based education, parternships.

\section{Publisher:}

International Society of Applied Preventive Medicine i-gap

CSWHI 2016; 7(4): 67 - 70; DOI 10.22359/cswhi_7_4_10 @ 2016 Clinical Social Work and Health Intervention

\section{Abstract:}

Developing future health care leaders continues to emphasize the need for competency based education. Given the increasing impact global health issues has on health status and population health on a country, graduate health care management program should include exposure to knowledge and skills in the curriculum. The geographic boundaries of domestic based graduate education often limit the ability for global engagement. Many student experiences diversity among the profile in 
classroom, whether on-line or residential, and some content related material on global issues. The paper reviews a strategic global partnership model used to expose students to health issues and health systems using study abroad learning. A three-year case study between partner institutions in North and South America is examined. The findings identify critical factors and best practices needed for sustaining global health partnerships.

\section{Introduction}

The movement towards Competencybased Health Management Education is well underway. Demands from stakeholders continue to push the need for capable healthcare leaders who are high performers engaging in various domains of management. Assessment and continuous development of healthcare managers is needed. Several competency models and assessment exist such as the Healthcare Leadership Alliance and American College of Health Executives 2016 Competencies Assessment tool identifying competency attainment in five domains (ACHE, 2016). The International Hospital Federation (2015) has also identified leadership competencies required for healthcare leaders to be effective in global environments. Several other models exist. A core component to competency development in both academic and clinical settings depends upon the translation of theory to practice. The additional challenge in preparing students and clinicians for global work is providing an environment and context for competency development. Truong, Paradies and Priest (2014) discuss theory to practice through specific interventions aimed at developing cultural competency in healthcare professionals to improve patient healthcare outcomes. Opportunities for students to gain exposure to context where cultural competence can be developed is particularly important when dealing with health disparities and social justice issues (Rajaram \& Bockrath, (2014).
Although workforce and classroom diversity exposes individuals to ethnic and cultural activities, it is far from a full emersion experience that often occurs in study abroad or Physicians Without Borders opportunities to develop global health competencies. This article describes how strategic global partnerships are formed to provide a platform for health management education, research, and service. Special emphasis is placed on a North American and South American partnership between academic and health institutions.

\section{Steps in Partnership Formation and Structure}

Building global partnerships is an enduring process that requires a vested interest by at least two individuals. Common values and intention to fortify a lasting relationship needs to be present. An essential first step is commitment, in most cases volunteerism, by a few individuals to establish the partnership. The perseverance to work through the technology, language, time, and other potential barriers is needed. Cultural competence, respect, and appreciation for the hard work to form a partnership is needed in the early stages. Without this commitment early partner-ship formation is virtually impossible. Once the intention is present by the vested individuals, in many cases faculty and clinicians, buy-in from senior leadership is needed. If the institutions where the vested individuals preside, proclaim as part of their mission global outreach, service, 
or collaboration, support is more easily obtained. The strategic plan can then serve as the basis for supporting the global partnership with direct and indirect backing. Direct support can be in the form of financial and human resources. Indirect support can be in the formal documentation to establish ongoing partnership activities. Evidence of ongoing faculty and clinician teaching, scholarship, and service can eventually lead to resource allocation from the institution.

A memorandum of understanding (MOU) serves as a basic document that outlines the mutually agreed upon activities of the global partnership. Initially, the MOU is intended to facilitate less formal activities such as faculty to faculty research and teaching; clinical peer to peer sharing; hosting student lectures. As the partnership grows, the MOU can be modified to include more formal initiatives such as enrolling in classes, joint degrees, and other educational endeavors to provide context for global health management competency development.

University-based partnerships often serve as the platform for global health education initiatives to flourish. Universities have historical foundation and stability to support sustainable partnerships. University-based partnerships are more stable resulting from long-standing faculty commitment to education. Additionally, many health management and allied health professions schools have existing clinical-based partners who have staff willing to support educational endeavors intended to support global health education and population health.

\section{Critical Factors in Sustaining Health Management Partnerships}

There are several factors that contribute to the success of health management partnerships. Some of these factors include:
- Institutional support

- University-based and health institutionbased partnerships

- Faculty scholarship and research

- Co-teaching between partner institutions

- Student learning

- Service-orientation

- Building on existing global partnerships

- Friendship and common ground

- Succession planning

- Early/mid-careerist commitment

Institutional support is a key element to sustainability. Senior administration needs to recognize and commit to long-term engagement. This is more likely when faculty or clinicians have established a track record of research and scholarship, teaching, and opportunities for students to participate in service learning. Service orientation, social justice, and principles of human rights can serve as the premise for ongoing collaboration.

Building upon existing partnerships provides a solid framework for sustainability. Health Management Partnerships that have realized long term accomplishments can be used to form multi-national models. Recently, partners from St. Elizabeth University, Slovakia, PUC-RIO, Brazil, and the University of Scranton, USA, conducted a global forum for health services research in January 2016. The Scranton-Slovakia Health Management Education Partnership was established in 1995 (West 1995) and the Scranton-Brazil Health Management Education partnership was established in 2013 to include University and Health Institutions.

\section{Conclusion}

Global Health Management Education Partnerships provide opportunities for students, faculty, and clinical staff to engage in 
educational activities that supports holistic personal development. Emma-Louise Aveling and Grahman Martin (2013) describe the transformative nature of international healthcare partnerships in developing countries beyond traditional market forces and nationalistic initiatives. Julio Frenk and Suerie Moon (2013) recognize the challenges for governance in global health settings. Through university-based and healthcare based initiatives, governance is more informed through individual leadership and partnership agreements at a more micro-level.

Long-term and short-term study abroad: student research; faculty teaching; exposure to social justice issues in underserved communities in both Brazil and United States can provide the contextual setting for global competencies to be developed. Acknowledging the importance of global health, nurturing healthcare leaders who understand the impact of global health at a local level, and obtaining buy-in from institutional administrators can establish Global Health Education Management Partnerships that birth the future of healthcare system delivery designed to meet the needs of a global society.

\section{References}

1. American College of Healthcare Executives (2016). ACHE Healthcare Executive Competencies Assessment Tool 2016. Retrieved on February 22, 2016 from https://www. ache.org/pdf/nonsecure/careers/competencies_booklet.pdf

2. Aveling, E-L., Martin, G. (2013). Realizing the transformative potential of healthcare partnerships: Insights from divergent literatures and contrasting cases in high-and low-income country contexts. Journal of Social Science \& Medicine: 92, 74-82.

3. Frenk, J., Moon, S. (2013). Governance Challenges in Global Health. The New England Journal of Medicine: 368, 936-42. DOI: 10.1056/NEJMra1109339.

4. International Hospital Federation (2015). Leadership competencies for healthcare services managers. Retrieved February 22, 2016 from https:/www.ihf- fih.org/resources/pdf/ Leadership_Competencies_for_Healthcare_ Services_Managers.pdf

5. Rajaram, Shireen S., Bockrath, S. (2014). Cultural Competence: New Conceptual Insights into its Limits and Potential for Addressing Health Disparities. Journal of Health Disparities Research and Practice: Vol. 7: Is. 5, Article 6.

6. Truong, M., Paradies, Y., Priest, N (2014). Interventions to improve cultural competency in healthcare: a systematic review of reviews. BMC Health Services Research: (14) 99.

7. West, D. (1995). Building relationships in developing and growing economies. BRIDGE Model. University of Scranton, PA. 